\title{
Rapid screening for phytoplasma presence in flower crops using tuf gene barcode
}

\author{
N. Contaldo, S. Paltrinieri, M.G. Bellardi, F. Lesi, E. Satta, and A. Bertaccini* \\ Department of Agricultural Sciences, Plant Pathology, Alma Mater Studiorum-University of Bologna, Italy
}

\begin{abstract}
Several molecular markers are currently available for phytoplasma strain discrimination. However, these markers often cannot be used for identification of phytoplasmas belonging to different ribosomal groups, or are not suitable for routine diagnostics. The DNA barcode amplicon based on the elongation factor Tu (tuf) gene for universal phytoplasma identification $(420-444 \mathrm{bp})$ was employed for verification of phytoplasma presence in samples from different plant species in PCR/RFLP analyses. Samples from 13 flower species showing symptoms suggesting phytoplasma presence and from corresponding asymptomatic plants were tested. The symptomatology present in the tested samples ranged from virescence in orchid, narcissus, Centaurium erythraea, primula, gladiolus, surphinia and hydrangea, to phyllody and/or flower malformation in ranunculus, carnation, petunia, statice, helicrysum, and gerbera. PCR amplicons of the expected size were obtained from all symptomatic samples. No amplicons were obtained from symptomless plants of the same species or negative controls devoid of DNA. The RFLP analyses carried out with TruI, Tsp509I, TaqI restriction enzymes allowed the differentiation among phytoplasmas in 3\% agarose gels and was useful for rapid screening of large sample numbers. The phytoplasma differentiation achieved is in agreement with published phytoplasma groupings based on $16 \mathrm{~S}$ rDNA. In case of phytoplasmas relevant for quarantine, sequencing may be necessary for confirmation. Tuf reference barcodes are deposited in the NCBI GenBank and in the Q-bank (http://www.qbank.eu/Phytoplasmas/), a freely available online identification tool for plant pests and pathogens of quarantine status.
\end{abstract}

Keywords: PCR, plant disease, molecular identification, RFLP, quarantine

\section{INTRODUCTION}

Increasing international plant propagation material trade in recent years is a cause of increasing risk of dissemination of unwanted or quarantine organisms. Moreover, climate change may increase the ability of plant pests to survive in regions other than those of their origin. To regulate and control plant pathogens there is a need for efficient and reliable identification and detection tools. A European project (Q-BOL) and the followup (Q-Bank) resulted in production and deposit in a dedicated portal of many barcode sequences of phytoplasmas collected worldwide (Bertaccini et al., 2011; Contaldo et al., 2014). The majority of these strains are currently maintained in live plant material in micropropagation (Bertaccini, 2015). Using such phytoplasma strain a barcode amplification with a cocktail primer system was developed on a 435 bp region of the tuf gene (Makarova et al., 2012). The usefulness of this fragment also in RFLP analyses for preliminary differentiation of phytoplasma ribosomal groups and/or 'Candidatus Phytoplasma' species has been reported

*Email: assunta.bertaccini@unibo.it 
(Contaldo et al., 2011). In this study, samples maintained as extracted nucleic acid from 13 ornamental plant species showing phytoplasma symptoms (Figure 1) were tested to verify the usefulness of this method in detection and identification of phytoplasmas in fieldcollected (stored) and fresh nucleic acid.

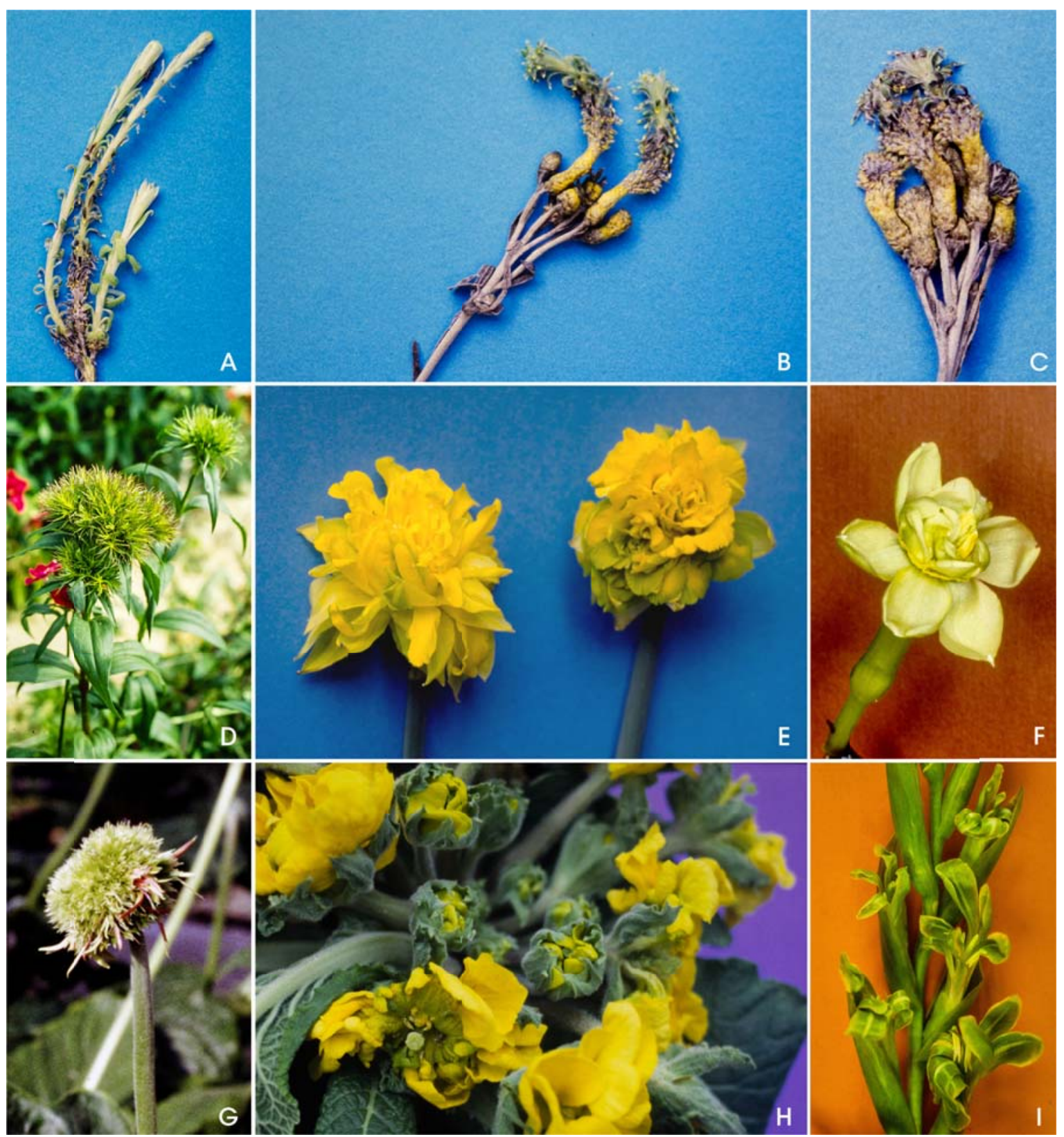

Figure 1. Symptoms of phytoplasma associated diseases in ornamental plant species collected in Italy: A-C, samples of Helicrysum italicum showing abnormal shoot elongation (A), lack of flowers and phyllody (B-C); D, Dianthus barbatus (carnation) with severe phyllody; E, Narcissus pseudonarcissus with virescence and flower malformation; F, Narcissus spp. with virescence; G, Gerbera jamesonii with severe phyllody, only a few external petals still have colour but are strongly malformed; $\mathrm{H}$, potted plant of Primula spp. with flower malformation and virescence; I, inflorescence of Gladiolus spp. with virescence. 


\section{MATERIALS AND METHODS}

\section{Samples}

Samples from different plant species showing phytoplasma-related symptoms were used for PCR with primers amplifying the tuf gene in a cocktail nested PCR reaction. Nucleic acids extracted from 1993 to 2015 with a chloroform/phenol procedure (Prince et al., 1993) from about 80 samples belonging to 13 plant species, and from corresponding samples collected from symptomless plants, all maintained as dry pellets at $4^{\circ} \mathrm{C}$, were used. Some samples were already determined to be phytoplasma positive using standard PCR/RFLP procedures based on the $16 S$ rRNA gene at the time of nucleic acid extraction (Duduk et al., 2013). Other samples were only tested with the current procedure. In PCR reactions, 20-60 ng of DNA suspended in TE buffer was used as template with primers Tuf340/Tuf890 (Table 1). Nested primers Tuf400/Tuf835 (Table 1) were used in subsequent PCR reactions where $1 \mu \mathrm{l}$ of a 1: 30 dilution (vol/vol) of the original PCR amplicon was used as template. RFLP analyses were carried out on 200 ng of DNA of each amplicon with Tru1I and Tsp509I restriction endonucleases (Fermentas, Vilnius, Lithuania) following the instruction of the manufacturer. Restriction profiles were analyzed in agarose 3\% (wt/vol) gels in TBE buffer and compared with reported phytoplasma profiles for identification (Contaldo et al., 2011).

Table 1. Primer combination employed for tuf gene barcode detection of phytoplasmas (from Makarova et al., 2012).

\begin{tabular}{cl}
\hline Primers & Sequence 5'-3' \\
\hline & \multicolumn{1}{c}{ PCR } \\
\hline Tuf340a & GCTCCTGAAGAAARAGAACGTGG \\
Tuf340b & ACTAAAGAAGAAAAAGAACGTGG \\
Tuf890ra & ACTTGDCCTCTTTCKACTCTACCAGT \\
Tuf890rb & ATTTGTCCTCTTTCWACACGTCCTGT \\
Tuf890rc & ACCATTCCTCTTTCAACACGTCCAGT \\
\hline & \multicolumn{1}{c}{ Nested PCR } \\
\hline Tuf400a & GTAAAACGACGGCCAGTGAAACAGAAAAACGTCAYTATGCTCA \\
Tuf400b & GTAAAACGACGGCCAGTGAAACTTCTAAAAGACATTACGCTCA \\
Tuf400c & GTAAAACGACGGCCAGTGAAACATCAAAAAGACAYTATGCTCA \\
Tuf400d & GTAAAACGACGGCCAGTGAAACAGAAAAAAGACAYTATGCTCA \\
Tuf400e & GTAAAACGACGGCCAGTCAAACAGCTAAAAGACATTATYCTCA \\
Tuf835ra & TAATACGACTCACTATAGGGAACATCTTCWACHGGCATTAAGAAAGG \\
Tuf835rb & TAATACGACTCACTATAGGGAACACCTTCAATAGGCATTAAAAAWGG \\
Tuf835rc & TAATACGACTCACTATAGGGAACATCTTCTATAGGTAATAAAAAAGG \\
\hline
\end{tabular}

\section{RESULTS AND DISCUSSION}

PCR products of the expected size (435 bp) were obtained from about one third of the samples tested (29/80). Amplicons were not observed in the negative controls devoid of 
DNA or in samples from asymptomatic plants. RFLP analyses allowed the differentiation at the 16Sr DNA group level of the phytoplasma sequences amplified. Aster yellows phytoplasmas were detected in the majority of the samples. In surphinia and narcissus, phytoplasmas in group 16SrIII (X-disease) and 16SrVI (clover proliferation), respectively, were identified for the first time in these species (Table 2). Some of the aster yellows phytoplasma also the first report of phytoplasmas in species such as $H$. italicum and Phalenopsis spp. The aster yellows phytoplasma was also reported for the first time in carnation, only recently reported to host "stolbur" phytoplasmas in Serbia (Josić et al., 2015).

Table 2. Results of PCR/RFLP characterization on the tuf genes for the ornamental plant samples studied.

\begin{tabular}{lllll}
\hline No. & Sample & $\begin{array}{l}\text { Year } \\
\text { collection }\end{array}$ & $\begin{array}{l}\text { 16S } \\
\text { rDNA* }\end{array}$ & RFLP results on tuf gene \\
\hline 1. Helicrysum italicum 5 & 12.10 .1993 & No & aster yellows-16SrI \\
2. Ranunculus 1 & 22.9 .1993 & Yes & aster yellows-16SrI \\
3. Ranunculus 4 & 22.9 .1993 & Yes & aster yellows-16SrI \\
4. Gladiolus 2 & 5.4 .1993 & Yes & aster yellows-16SrI \\
5. Gladiolus 1 & 2.7 .1994 & Yes & aster yellows-16SrI \\
6. Carnation 4 & 10.1 .1996 & No & aster yellows-16SrI \\
7. Carnation 5 & 10.1 .1996 & No & aster yellows-16SrI \\
8. Carnation 6 & 10.1 .1996 & No & aster yellows-16SrI \\
9. Ranunculus 1 & 10.1 .1996 & Yes & aster yellows-16SrI \\
10 Ranunculus 2 & 10.1 .1996 & Yes & aster yellows-16SrI \\
11 Primula 10 & 28.4 .1996 & No & aster yellows-16SrI \\
12 Surphinia & 16.7 .1996 & No & x-disease-16SrIII \\
13 Carnation 5 & 18.2 .1997 & No & aster yellows-16SrI \\
14 Gerbera 4 & 1.7 .1997 & Yes & aster yellows-16SrI \\
15 Narcissus 1 & 6.3 .1998 & No & clover proliferation-16SrVI \\
16 Narcissus 2 & 6.3 .1998 & No & clover proliferation-16SrVI \\
17 Primula 4 & 11.5 .1998 & No & aster yellows-16SrI \\
18 Primula 11 & 11.5 .1998 & No & aster yellows-16SrI \\
19 Petunia 1 & 25.5 .1998 & No & aster yellows-16SrI \\
20 Petunia 2 & 25.5 .1998 & No & aster yellows-16SrI \\
21 Petunia 3 & 25.5 .1998 & No & aster yellows-16SrI \\
22 Centaurium erythraea 1 & 3.6 .1998 & Yes & aster yellows-16SrI \\
23 Centaurium erythraea 9 & 3.6 .1998 & Yes & aster yellows-16SrI \\
24 Phalenopsis spp. & 21.10 .2013 & Yes & aster yellows-16SrI \\
25 Hydrangea 3 & 9.4 .2015 & Yes & aster yellows- 16SrI \\
26 Hydrangea 1 & 17.5 .2015 & Yes & aster yellows-16SrI \\
27 Hydrangea 2 & 17.5 .2015 & Yes & aster yellows-16SrI \\
28 Statice 1 & 10.10 .2015 & Yes & aster yellows-16SrI \\
29 Statice 2 & 10.10 .2015 & Yes & aster yellows-16SrI \\
\hline
\end{tabular}

*Yes, amplified sample; No, not amplified or not tested 
From Table 2 it appears that 14 of 29 samples tested were amplified only with tuf gene primers. However, RFLP analyses of these amplicons alone allowed phytoplasma identification suggesting that the methodology is useful for screening a large number of samples since it is also rapid and inexpensive. It is therefore confirmed that RFLP profiles are consistent with those of reference phytoplasma strains, and are in agreement with published groupings based on the 16S rDNA (Lee et al., 1998).

The barcode taxonomic method uses a short DNA marker to identify unknown organisms. It differs from molecular phylogeny in that the main goal is not to determine classification, but to identify an unknown microorganism (sample) in terms of a known classification. It offers accurate identification, strengthening the link between traditional and molecular taxonomy. It is therefore advisable that, in case of phytoplasmas relevant for quarantine, sequencing and/or amplification of the $16 S$ rRNA gene is used in addition to RFLP analyses for confirmation of phytoplasma identity. While the phytoplasma DNA barcoding protocol based on the tuf gene has been shown to identify phytoplasmas belonging to the groups $16 \mathrm{SrI}, 16 \mathrm{SrII}, 16 \mathrm{SrIII}, 16 \mathrm{SrIV}, 16 \mathrm{SrV}$, 16SrVI, 16SrVII, 16SrIX, 16SrX, 16SrXI, 16SrXII, 16SrXIV, 16SrXX and 16SrXXI (Contaldo et al., 2015), the use of the RFLP on the barcode amplicon allows less group/subgroup differentiation However, by using the two reported enzymes the majority of phytoplasma groups could be discriminated (Contaldo et al., 2011).

\section{CONCLUSIONS}

The reported study confirms that it is possible to use tuf gene amplification followed by RFLP analyses with informative enzymes for the preliminary phytoplasma detection and identification. The method is quick and inexpensive and can be applied to field-collected samples maintained for a long period of time in storage as extracted nucleic acid. In case of sequencing for phytoplasma identification, the tuf reference barcodes were deposited in the NCBI GenBank, and in the Q-bank (http://www.q-bank.eu/Phytoplasmas/), a freely available online identification tool for plant pests and pathogens of quarantine status.

\section{Literature cited}

Bertaccini, A. (2015). Phytoplasma Collection, http://ipwgnet.org/collection.

Bertaccini, A., Paltrinieri, S., Makarova, O., Contaldo, N., and Nicolaisen, M. (2011). Sharing information and collections on phytoplasmas: from Q-Bol to Q-Bank. Bull. Insectol. 64(Suppl.), S289-S290.

Contaldo, N., Canel, A., Makarova, O., Paltrinieri, S., Bertaccini, A., and Nicolaisen (2011). 2011. Use of a fragment of the tuf gene for phytoplasma 16Sr group/subgroup differentiation. Bull. Insectol. 64(Suppl.), S45-S46.

Contaldo, N., Bertaccini, A., and Nicolaisen, M. (2014). Q-bank phytoplasma database. Phytopath. Mollicutes 4(1), $1-4$.

Contaldo, N., Paltrinieri, S., Makarova, O. Bertaccini, A., and Nicolaisen, M. (2015). Q-bank Phytoplasma: a DNA bar-coding tool for phytoplasma identification. Chapter 10 In: C. Lacomme editor. Plant Pathology, Techniques and Protocols, Methods in Molecular Biology, Springer, 1302: 123-135.

Duduk, B., Paltrinieri, S., Lee, I-M., and Bertaccini, A. (2013). Nested PCR and RFLP analysis based on the 16S rRNA gene. Meth. in Mol. Biol. 938, 159-171.

Josic, D., Starović, M., Kojic, S., Pivic, R., Stanojkovic-Sebic, A., Zdravkovic, M., and Pavlovic, S. (2015). Dianthus barbatus-A new host of stolbur phytoplasma in Serbia. Pl. Dis. 99(2), 283-283. 
Lee, I-M., Gundersen-Rindal, D.E., Davis, R.E,, and Bartoszyk, I.M. (1998). Revised classification scheme of phytoplasmas based on RFLP analyses of $16 \mathrm{~S}$ rRNA and ribosomal protein gene sequences. Int. J. Syst. Bacteriol. 48, 1153-1169.

Makarova, O., Contaldo, N., Paltrinieri, S., Kawube, G., and Bertaccini, A. 2012. DNA barcoding for identification of 'Candidatus Phytoplasmas' using a fragment of the elongation factor tu gene. PLoS ONE 7(12), 1-9.

Prince, J.P., Davis, R.E., Wolf, T.K., Lee, I-M., Mogen, B.D., Dally, E.L., Bertaccini, A., Credi, R., and Barba, M. (1993). Molecular detection of diverse mycoplasma-like organisms (MLOs) associated with grapevine yellows and their classification with aster yellows, X-disease, and elm yellows MLOs. Phytopathology 83, 1130-1137. 